ISSN 2311-875X (Online)

Нацииональные интересы

ISSN 2073-2872 (Print)

ТРАНСГРАНИЧНОЕ ВЗАИМОДЕЙСТВИЕ РЕГИОНОВ СИБИРИ И МОНГОЛИИ

Ай-кыс Чамдаловна КЫЛГЫДАЙ ${ }^{\mathrm{a}, \bullet}$, Тана Михайловна ОЙдУП

a научный сотрудник лаборатории региональной экономики,

Тувинский институт комплексного освоения природных ресурсов СО РАН, Кызыл, Российская Федерация

aikys_k@mail.ru

${ }^{\mathrm{b}}$ кандидат социологических наук, ученый секретарь Тувинского института комплексного освоения

природных ресурсов СО РАН, Кызыл, Российская Федерация

tana_o@mail.ru

• Ответственный автор

\section{История статьи:}

Принята 09.09.2016

Принята в доработанном виде 02.10 .2016

Одобрена 26.10.2016

Доступна онлайн 27.02.2017

УДК 339.96

JEL: F02, F53, O53, O57, Z18

Ключевые слова:

приграничные регионы,

сотрудничество, пограничные пункты пропуска

\begin{abstract}
Аннотация
Тема. Статья посвящена анализу трансграничного сотрудничества регионов Сибири и Монголии. Рассмотрено межстрановое взаимодействие российско-монгольского приграничья, которое представляют с российской стороны Республики Бурятия, Тыва, Алтай, Забайкальский край, с монгольской - Баян-Улэгэйский, Хэнтэйский, Убсунурский, Дзабханский, Хубсугульский, Булганский, Селенгинский, Восточный аймаки.

Цели. Анализ положения каждого приграничного региона в отдельности, определение уровня взаимодействия между сторонами. Оценка того, насколько активно используется «ресурс границы» местными властями, каковы объективные причины низкой приграничной активности.

Методология. В работе использован сравнительный анализ взаимодействия регионов Сибири и Монголии.

Результаты. Определено, какие российские приграничные регионы в большей степени включены в трансграничное взаимодействие, какую роль играет в этом количество пограничных пропускных пунктов, в особенности их статус. Установлено, что для наращивания трансграничного взаимодействия необходимо расширение сети пунктов пропуска, повышение их статусов с двусторонних до международных, а также модернизация приграничной инфраструктуры.

Область применения. Результаты, представленные в статье, будут полезны всем заинтересованным лицам, которые задействованы в расширении и углублении межгосударственного сотрудничества.

Выводы. Экономический эффект приграничного сотрудничества связан с расширением рынка сбыта для одних участников приграничных связей и получением более дешевых товаров и услуг - для других. При этом необходимо отметить, что любые позитивные административные начинания с двух сторон по расширению взаимодействия в сферах культуры, туризма, сельского хозяйства, добывающей промышленности, торговли и т.д. могут не получить развития и не принести положительных результатов при отсутствии развитой приграничной инфраструктуры.
\end{abstract}

(C) Издательский дом ФИНАНСЫ и КРЕДИТ, 2016
В условиях формирования единого рыночного пространства особое значение приобретает обоснование путей интеграции экономики на всех уровнях экономических сообществ, территорий. Современное экономическое развитие характеризуется ярко выраженной тенденцией интеграции национальных экономик в единый межхозяйственный комплекс, стремлением к созданию обширных зон свободной торговли, к повышению роли международных соглашений по обмену товарами и услугами. Внешние экономические связи превратились в важнейший фактор экономического роста, имеют особое значение для развития приграничных регионов и в большинстве случаев служат стимулом для интеграции в экономику сопредельных стран [1].
В современных условия развития интеграционных взаимодействий в социальноэкономической, культурной, экологической, природоохранной сферах приграничные территории могут рассматриваться как единые трансграничные территории, для которых необходима разработка согласованных между странами единых программ развития. Именно трансграничные территории в первую очередь являются индикатором эффективности геополитического и экономического сотрудничества. Между тем приграничные территории азиатской России по темпам социально-экономического развития продолжают отставать от регионов европейской части страны [2]. 
Конец XX - начало XXI вв. можно охарактеризовать как период усиления интеграционных связей не только на территории Евросоюза, но и в странах Центральной Азии. В настоящее время после проявления некоторых центробежных процессов отмечается заметная активизация сотрудничества и в рамках АТР, и на пути вовлечения в интеграционные процессы иных стран, причем как на пути экономического, так и стратегического партнерства [3].

В последние десятилетия активизировались процессы глобализации не только между крупными экономическими сообществами, государствами, но и на уровне приграничных регионов. Так, динамичное развитие приграничных контактов является характерной особенностью современного этапа международных экономических отношений, приграничные территории все в большей степени становятся «точками роста» экономики ${ }^{1}$ [4-7].

Известно, что приграничное положение территории является ресурсом развития экономики региона, а приграничное сотрудничество дает импульс развитию экономики приграничных регионов, которые по большей части относятся к регионам с низким уровнем развития, но при этом обладают богатейшим природно-сырьевым потенциалом. В стратегии территориального развития РФ и еe интеграции в мировую экономику приграничным территориям отводится роль форпостов, необходимого звена международного экономического сотрудничества [8].

Российско-монгольское приграничье представляют c российской стороны три национальные республики Сибири - Бурятия, Тува, Алтай, а также Забайкальский край, с монгольской Баян-Улэгэйский, Хэнтэйский, Убсунурский, Дзабханский, Хубсугульский, Булганский, Селенгинский, Восточный аймаки². Общая протяженность государственной границы в данном регионе - 3316,2 км.

Между обеими странами давно налажены двусторонние дипломатические отношения. Россия имеет посольство в столице Монголии Улан-Баторе, а также генеральное консульство в Дархане и генеральное консульство в Эрдэнэте,

\footnotetext{
${ }^{1}$ Мангатаева Д.Д., Осодоев П.В. Историко-географические и социально-экономические предпосылки развития экономического сотрудничества приграничных территорий России и Монголии // Вестник Бурятского государственного университета. 2007. № 3. C. 33-39.

2 Незамайкин В.Н. Интеграция России в процесс глобализации: природно-ресурсный аспект // Финансы и кредит. 2006. № 3. С. 16-21.
}

а Монголия - посольство в Москве, а также генеральные консульства в Иркутске, Кызыле и Улан-Удэ и почетное консульство в Екатеринбурге.

С советских времен Россию и Монголию связывают теплые дружеские отношения, которые были перенесены впоследствии на российскомонгольские деловые связи. Вместе с тем объем двусторонней торговли резко упал в 1990-е гг., a по состоянию на 2010-е гг. представлен преимущественно поставками российских энергоносителей. В связи с падением мировых цен на нефть в 2015 г. объем двустороннего товарооборота резко сократился и составил около 1 млрд долл. США (в 2014 г. он был равен 1,6 млрд долл. США) ${ }^{3}$.

По состоянию на конец 2015 г. первое место по экспортно-импортным отношениям среди приграничных российских регионов занимала Республика Бурятия; за период январь-декабрь 2015 г. Бурятия экспортировала товаров на 26 109,1 тыс. долл. США (табл. 1). По импорту Бурятия также имеет наибольший товарооборот это 6 110,8 тыс. долл. США. Меньше всего экспортирует Тува; за аналогичный период оборот составил только 413 тыс. долл. США, в то время как в Бурятии - 32220 тыс. долл. США.

Следует отметить, что в 2015 г. по сравнению с 2014 г. товарная номенклатура экспортируемого товара во всех приграничных регионах увеличилась в 2-2,5 раза. Такая большая разница в доле участия регионов в торговых отношениях c соседней страной подтолкнула нас к более детальному анализу приграничного положения каждого региона в отдельности, а также уровня взаимодействия между сторонами. Кроме того, представлялось полезным выяснить, насколько активно используется «ресурс границы» местными властями, каковы объективные причины низкой приграничной активности.

Во всех приграничных субъектах обеих стран региональные власти активно участвуют в расширении и углублении торговых, экономических и культурных связей между своими регионами и пограничными аймаками Монголии, свидетельством чего служат многочисленные подписанные двусторонние соглашения.

\footnotetext{
${ }^{3}$ Филин С.А., Дугаржав Л., Параскева С.Б. Современное развитие инновационного взаимодействия сферы малого и среднего предпринимательства России и Монголии - продолжение многовековых российско-монгольских отношений (к 70-летнему юбилею исторической победы советско-монгольских войск при Халхин-Голе // Национальные интересы: приоритеты и безопасность. 2009. № 15. C. 7-22.
} 
Развитие приграничной инфраструктуры является одним из важных факторов интенсификации приграничного сотрудничества. Российскомонгольская граница характеризуется низкой насыщенностью пунктами пропуска. Так, в приграничных регионах расположены 10 пунктов пропуска через государственную границу РФ восемь автомобильных (три многосторонних ${ }^{4}$, пять двусторонних ${ }^{5}$ пунктов пропуска, два железнодорожных пункта пропуска (табл. 2).

Концепцией таможенного оформления и таможенного контроля товаров в местах, приближенных к государственной границе Российской Федерации, предусмотрено совершение таможенных операций, для чего в приграничных регионах запланировано создание сети таможенно-логистических терминалов (ТЛТ). В соответствии с Перечнем таможеннологистических терминалов (далее - ТЛТ), в зоне деятельности Сибирского таможенного управления запланировано создание:

- три ТЛТ в первоочередном порядке, а именно: Забайкальского (Читинская таможня), Ташантинского (Алтайская таможня) и Кяхтинского (Бурятская таможня);

- шесть ТЛТ в долгосрочной перспективе (до 2020 г.) вблизи отдельных пунктов пропуска, расположенных в регионе деятельности Бурятской, Читинской и Тувинской таможен.

Протоколом заседания комиссии ФТС России по реализации Концепции таможенного оформления и таможенного контроля в местах, приближенных к государственной границе Российской Федерации, утверждено создание ТЛТ ОАО «ТрансКонтейнер» в непосредственной близости от многостороннего железнодорожного пункта пропуска «Забайкальск».

В апреле 2016 г. Сибирским таможенным управлением в ФТС России направлено предложение о создании ТЛТ ООО «ТЛТ-Забайкальск», расположенного в

\footnotetext{
${ }^{4}$ Многосторонние пункты пропуска - служат для пересечения государственной границы Российской Федерации лицами независимо от их гражданства (подданства), в том числе лицами без гражданства, и транспортными средствами независимо от государственной принадлежности, а также для перемещения через нее грузов, товаров и животных независимо от их государственной принадлежности.

5 Двусторонние пункты пропуска - служат для пересечения государственной границы Российской Федерации гражданами, в том числе в упрощенном порядке, и транспортными средствами Российской Федерации и сопредельного государства, а также для перемещения через государственную границу Российской Федерации грузов, товаров и животных только Российской Федерации и сопредельного государства.
}

непосредственной близости от многостороннего автомобильного пункта пропуска «Забайкальск».

Таким образом, сравнивая вид и статусы пунктов пропуска у приграничных регионов, можно сказать, что наличие железнодорожного сообщения способствует ведению активных торговых сообщений; примером могут служить Республика Бурятия и Забайкальский край. Однако в Бурятии железнодорожный пункт пропуска имеет статус международного, а в Забайкальском крае - двустороннего, что позволяет республике осуществлять пропуск граждан, грузов и товаров независимо от их государственной принадлежности. В то же время статус двустороннего дает Забайкальскому краю право, хоть и в упрощенном режиме, пропускать граждан, грузы и товары, но только сопредельного государства, а именно Монголии.

В то же время количество пунктов пропуска не гарантирует высокого товарооборота между сторонами; так, например, в Республике Тыва три автомобильных пункта пропуска для двустороннего пассажирского и грузового сообщения, а в Республике Алтай только один, но имеющий статус многостороннего.

Одним из важных факторов интенсификации приграничного сотрудничества является развитие приграничной инфраструктуры. Потребности в качественной инфраструктуре постоянно растут, однако в условиях мирового финансового кризиса вложения в нее стали сокращаться. Рост мировой экономики в последние годы замедляется. И, как показывает новое исследование агентства McKinsey, одна из причин этого - недостаточные вложения в инфраструктуру. Сегодня многие руководители государств и компаний заявляют, что инфраструктура для них - приоритет номер один. Но на деле во многих регионах, в том числе в США, Мексике, ряде стран Евросоюза и в России, инфраструктурные инвестиции сокращаются. Чаще всего под ударом оказываются вложения в автодороги и телекоммуникации ${ }^{6}$.

Недостаточное количество переходов, таможенных пунктов и других элементов приграничной инфраструктуры является сдерживающим фактором приграничного сотрудничества между Россией и Монголией. Также особого внимания требует развитие сервисных услуг транспорта, сферы услуг, оптовой и розничной торговли в муниципальных образованиях и аймаках.

\footnotetext{
${ }^{6}$ Борисова Д. Преодоление инфраструктурного отставания позволит поддержать экономический рост // Газета «Ведомости» от 05.07.2016.
} 
Республика Бурятия граничит на западе, севере и востоке $\mathrm{c}$ Республикой Тыва, Иркутской областью (с 500-километровым участком по акватории оз. Байкал) и Забайкальским краем. Южная граница Бурятии с Монголией является государственной границей Российской Федерации. Для Бурятии - приграничного российского региона - также представляется актуальным расширение интеграционных связей с соседствующими приграничными территориями. Важным фактором геополитического статуса Бурятии является ее пограничное положение общая граница с Монголией, которая здесь пересекается с основной для Монголии железной дорогой, связывающей еe с Россией, странами Европы, Средней и Ближней Азии. Это же направление служит наикратчайшим путем из европейских и сибирских регионов Российской Федерации в Китай $[9]$.

По территории Бурятии или в непосредственной близости от еe границ пролегают два транспортных коридора общегосударственного и даже межгосударственного значения. По южному - главному - располагаются Транссиб c проходящими вдоль него автомобильной магистралью, линиями высоковольтной электропередачи, a также железной дорогой в Монголию и Китай. По северному коридору проходит Байкало-Амурская магистраль, значение которой возросло после ввода в действие в конце 2003 г. Северо-Муйского тоннеля. Эти коридоры рассматриваются как возможные трассы магистральных трубопроводов для транспортировки нефти и газа в страны СевероВосточной Азии. Оба транспортных коридора, пролегая по южной и северной окраине Бурятии, открывают возможности для освоения внутренних районов республики, в настоящее время наименее развитых в экономическом отношении.

Развитие и углубление партнерства с Монголией по всем направлениям - в торгово-экономической, научно-технической, культурной областях (с особым акцентом на продвижение тех сфер взаимодействия, где совпадают долговременные интересы наших стран, а сотрудничество признано взаимовыгодным) является одним из приоритетов политики Республики Бурятия в области развития международных связей региона. К сожалению, темпы экономического взаимодействия России и Монголии недостаточно высоки. Россия

\footnotetext{
${ }^{7}$ Краснов М.А. Поиск новых транспортных стратегий России // Транспортная стратегия России (план-проект). Новосибирск, 2003. С. 717-723; Потапов Л.В., Добровенский Ю.П. Концептуальные основы региональной стратегии развития Республики Бурятия // Вестник БНЦ СО РАН. 2014. № 17. С. 109-111.
}

находится на 2-м месте во внешней торговле Монголии после Китая, однако Монголия рассчитывает к 2020 г. довести взаимный товарооборот до 10 млрд долл. США в год. Монголия традиционно заинтересована в продукции из Бурятии и, безусловно, взаимодействие в этом направлении - одно из самых перспективных 8 .

Наличие в Бурятии основных железнодорожных и автомобильных трасс, международных пунктов пропуска является основным фактором, определяющим более интенсивный характер трансграничных связей по сравнению с другими приграничными регионами. При смещении направлений грузопотоков из стран АТР через Монголию эти территории получат импульс для развития экономики. Намеченная модернизация Улан-Баторской железной дороги (строительство второго пути, электрификация) позволит обеспечить перевозку возрастающих объемов российско-китайских грузов. На территории Монголии, в г. Алтан-Булаг, на границе с Россией, создана зона свободной торговли, где планируется построить выставочные и торговые павильоны, складские помещения, офисы фирм и компаний, некоторые производственные объекты. Здесь будет осуществляться беспошлинная торговля, организовано безвизовое посещение. В соответствии со Стратегией социальноэкономического развития Республики Бурятия до 2027 г. намечено создать Центр приграничного сотрудничества (или ОЭЗ нового типа, например, «торгово-транспортную» в приграничном районе г. Кяхта и Наушки), что позволит в значительной мере использовать приграничный потенциал совместно с соседней торговой зоной «АлтанБулаг» ${ }^{9}$.

Забайкальский край, расположенный в восточной части Забайкалья граничит с Амурской и Иркутской областями, республиками Бурятия и Якутия. Южная и юго-восточная границы Забайкальского края являются государственной границей Российской Федерации с Монголией и КНР.

Сотрудничество Забайкальского края и Монголии осуществляется в соответствии с Соглашением между администрацией Читинской области Российской Федерации и правительственными

\footnotetext{
${ }^{8}$ Приглашаем предприятия Республики Бурятия на международную выставку «Ворота в Азию». Официальный сайт Министерства экономики Республики Бурятия.

URL: http://economy.govrb.ru/2013/news/?ELEMENT_ID=9358

${ }^{9}$ Стратегия социально-экономического развития Республики Бурятия до 2027 г.

URL: http://economy.buryatia.ru/econ/adm3_progr_dok.html
} 
организациями Монголии о торговоэкономическом, научно-техническом и культурном сотрудничестве от 1 марта 2002 г. [10].

В экспорте Забайкальского края в Монголию представлены в основном поставки продовольственной продукции (47\%), в импорте соль, сера, земли и камень, штукатурные материалы, известь (100\%). В последующие годы прогнозируется увеличение объемов экспорта продукции деревообрабатывающей и горнорудной промышленности. Это связано с реализацией проектов в области переработки леса, а также добычи и переработки полезных ископаемых, в том числе каменного угля.

Перспективным является сотрудничество в области энергетики, углубленной переработки минерального и животноводческого сырья, добычи полезных ископаемых, в строительстве объектов инфраструктуры и т.д. Начиная с 2000 г. осуществляются поставки электроэнергии на монгольские пункты пропуска «Ульхун» и «Эрэнцав» и близлежащие населенные пункты, подсоединен к линии электропередачи сомон Сэргэлэн Восточного аймака. Одним из приоритетных является взаимодействие в сфере сельского хозяйства, в частности поставки мяса на перерабатывающие предприятия Забайкальского края из Монголии, поставки племенного скота в приграничные аймаки. В области добычи полезных ископаемых от Забайкальского края взаимодействие с Монголией осуществляет ЗАО «Восток», которое ведет добычу россыпного золота в Восточном аймаке на месторождении Цааган-Чулууг, ежегодно добывая примерно 100 кг золота [1].

В рамках работ по расширению международного, приграничного сотрудничества и развития внешнеэкономической деятельности Забайкальского края необходимо:

$\begin{array}{lclr}\text { - создание } & \text { благоприятных } & \text { условий } & \text { для } \\ \begin{array}{l}\text { привлечения } \\ \text { экономику; }\end{array} & \text { иностранных } & \text { инвестиций } & \text { в }\end{array}$

- стимулирование экспортной деятельности хозяйствующих субъектов Забайкальского края;

- совершенствование приграничной инфраструктуры, включая обустройство и реконструкцию пунктов пропуска.

Республика Алтай является полноправным приграничным субъектом России, на северо-западе граничит с Алтайским краем, на северо-востоке с Кемеровской областью, на востоке - с Хакасией и Тувой, на юге - с Монголией и Китайской Народной Республикой, на юго-западе с Казахстаном. В Республике Алтай одновременно развивается сотрудничество с тремя приграничными зарубежными странами Монголией, Китаем и Казахстаном, причем взаимодействие с каждой из них имеет свою специфику. В частности, торговля Республики Алтай с аймаками Монголии в настоящее время развивается динамично наряду с процессами укрепления связей в сферах культурного и научнотехнического сотрудничества. В осуществлении внешнеэкономических связей с Монголией приоритет отдается западным аймакам (Кобдоскому, Баян-Улэгэйскому, Увсинскому) $^{10}$ [11].

Важным моментом в развитии торговых отношений Республики Алтай с Монголией и КНР является начало строительства в районе МАПП «Ташанта» на российско-монгольской границе транспортно-логистического терминала (ТЛТ), развитие которого осуществляется в соответствии с Концепцией таможенного оформления и таможенного контроля товаров в местах, приближенных к государственной границе Российской Федерации. При этом отмечается необходимость формирования развернутой инфраструктуры ТЛТ с учетом расширения номенклатуры перемещаемых товаров и заинтересованности деловых кругов Китая и Монголии в экспорте товаров народного потребления, мясопродуктов и полезных ископаемых в Россию, импорте леса и лесоматериалов из России. Предполагается, что дальнейшая активизация международного сотрудничества в условиях новой таможенной политики государства будет способствовать достоверному экономическому прогнозированию товаропотоков и налаживанию деловых связей между сопредельными субъектами Китая.

Строительство ТЛТ обеспечит прирост товарооборота через МАП «Ташанта» в связи с окончанием строительства автодороги протяженностью 210 км: Даян (Китай) - ЦааганНур (Монголия) - Ташанта (РФ), с выходом на Чуйский тракт России.

Республика Tыва, располагаясь в центральной части Азиатского материка, с одной стороны граничит с Республикой Горный Алтай,

\footnotetext{
${ }^{10}$ Барсуков А.М. Приграничное сотрудничество регионов Большого Алтая // Дневник АШПИ. 2015. № 31. С.190-195; Мансков С.A., Лукашевич Е.В., Красникова Т.С. и др. Управление имиджем и репутацией Алтайского края на территории Большого Алтая // PR и реклама в изменяющемся мире: региональный аспект. 2012. № 10 C. 3-5.
} 
Красноярским краем, Республикой Иркутской областью, Республикой Бурятия, с другой - исторически сложилась государственная граница России с Монголией. Сочетание выгодного географического положения, богатого природно-ресурсного потенциала определило привлекательность Республики Тыва для внешних партнеров ${ }^{11}$ [12-14].

В рамках действующего законодательства, регулирующего внешнеэкономическую деятельность, Республика Тыва традиционно поддерживает добрососедские дружественные взаимоотношения с соседней Монголией. На межрегиональном и приграничном уровнях налаживаются взаимовыгодные партнерские связи, обретает современные формы торговоэкономическое и культурное сотрудничество.

В Республике Тыва для активизации внешнеэкономической деятельности и увеличения внешнеторгового оборота правительством региона совместно с федеральными структурами рассматривается вопрос о совершенствовании транспортной инфраструктуры, придании федерального статуса автодороге Абакан Ак-Довурак - Чадан - Хандагайты - госграница.

Осенью 2015 г. новый маршрут этой трассы был официально перенесен с пограничного пункта «Цаган-Тологой» на КПП «Хандагайты Боршоо», который является самым ближним выходом на опорную сеть дорог Монголии. С реализацией проектов перенаправления федеральной автотрассы М-54 и модернизации КПП «Хандагайты - Боршоо» до многостороннего перехода с развитой таможенной инфраструктурой Тува, по мнению экспертов, становится важным звеном в трансграничном транспортном коридоре между Россией и Азиатско-Тихоокеанским регионом ${ }^{12}$.

Перенаправление федеральной трассы М-54 позволит наладить последовательное использование автомобильного трансграничного коридора Абакан (Хакасия) - Ак-Довурак Хандагайты (Тува) - Улангом - Ховд - Булган (Монголия) - Такишкен - Урумчи (АРВМ КНР) протяженностью около 2000 км. Значение данной автодороги для регионов Восточной Сибири возрастет с завершением строительства железной дороги Курагино - Кызыл. Следует сказать, что китайская сторона принимает активное участие в строительстве и совершенствовании монгольского участка дороги, который на сегодняшний день является малообустроенным и труднопроходимым для большегрузных автомобилей на участке Уенч Ховд - Улангом (600 км $)^{13}$.

В условиях транспортной изолированности, когда высокогорная приграничная республика связана c другими субъектами РФ лишь одной автомагистралью М-54, воздушный транспорт является неотъемлемой частью транспортной системы Тувы. Стратегическими мерами, направленными на развитие Тувы как трансграничной территории, является обеспечение свободного надежного доступа республики к внутрироссийской транспортной инфраструктуре и международным путям сообщения. Через территорию Тувы проходят: международный авиатранспортный коридор МВТ-А-91, автодорога, связывающая Россию с Монголией и Китаем (Кызыл - Чадан - Хандагайты - Улангом - Ховд Булган - Такишкен - Фукан Мичуань - Урумчи).

Рассматривая текущее состояние российскомонгольского приграничного сотрудничества, отметим, что оно базируется на обслуживании внешнеэкономических связей и развитии приграничной торговли, которая основывается на различии в уровне и соотношении цен на товары потребительского и производственного назначения в соседних странах. Экономический эффект такого сотрудничества связан с расширением рынка сбыта для одних участников приграничных связей и получением более дешевых товаров и услуг для других. При этом стоит заметить, что любые позитивные административные начинания с обеих сторон по расширению взаимодействия в сферах культуры, туризма, сельского хозяйства, добывающей промышленности, торговли и т.д. могут не получить положительного результата при отсутствии развитой приграничной инфраструктуры.

\footnotetext{
${ }^{11}$ Ойдуn T.М., Кылгыдай А.К.Ч. Особенности межэтнических связей населения монгольского приграничья // СОЦИС. 2012. № 6. C. $136-140$.

12 Глава Тувы договорился с Росграницей о реконструкции пограничного пропуска «Хандагайты-Боршоо» / Официальный портал Республики Тыва.

URL: http://gov.tuva.ru/press_center/news/activity/22468
}

\footnotetext{
13 Информация о межрегиональном и приграничном сотрудничестве Республики Тыва с Монголией. Официальный сайт Министерства экономики Республики Тыва. URL: http://mert.tuva.ru/suborgs/agency-foreigneconomic/relations/mool
} 
Таблица 1

Экспорт и импорт с Монголией в 2015 г., тыс. долл. США

Table 1

Export and import relations with Mongolia in 2015, thousand USD

\begin{tabular}{lcccccc}
\hline \multirow{2}{*}{ Субъект РФ } & \multicolumn{2}{c}{ Экспорт } & \multicolumn{2}{c}{ Импорт } & \multicolumn{2}{c}{ Оборот } \\
\cline { 2 - 8 } & Декабрь & $\begin{array}{c}\text { Январь- } \\
\text { декабрь }\end{array}$ & Декабрь & $\begin{array}{c}\text { Январь- } \\
\text { декабрь }\end{array}$ & Декабрь & $\begin{array}{c}\text { Январь- } \\
\text { декабрь }\end{array}$ \\
\hline Республика Алтай & 89,6 & 1692 & 32,2 & 118,9 & 121,8 & 1810,9 \\
\hline Республика Тыва & 82,9 & 413 & - & - & 82,9 & 413 \\
\hline Республика Бурятия & 2876,3 & 26109,1 & 223,8 & 6110,8 & 3100,2 & 32220 \\
\hline Забайкальский край & 129,4 & 2587,4 & - & 24,1 & 129,4 & 2611,5 \\
\hline
\end{tabular}

Источник: Федеральная таможенная служба. Сибирское таможенное управление. URL: http://stu.customs.ru/index.php? option=com_content\&view=article\&id=10754:-2014-\&catid=185:2012-12-27-01-30-55\&Itemid $=260$

Source: Federal Customs Service. Siberian Customs Department. Available at: http://stu.customs.ru/index.php? option=com_content\&view=article\&id=10754:-2014-\&catid=185:2012-12-27-01-30-55\&Itemid=260

\section{Таблица 2}

Пункты пропуска через российско-монгольскую границу

Table 2

Border crossing points through the Russian-Mongolian border

\begin{tabular}{|c|c|c|}
\hline Приграничный регион РФ & Вид и статус пункта пропуска & $\begin{array}{l}\text { Наименование пункта пропуска через } \\
\text { границу }\end{array}$ \\
\hline Республика Алтай & $\begin{array}{l}\text { Автомобильный (для международного } \\
\text { пассажирского и грузового сообщения) }\end{array}$ & МАПП Ташанта (РФ) - Цаган-Нур (Монголия) \\
\hline \multirow[t]{3}{*}{ Республика Тыва } & $\begin{array}{l}\text { Автомобильный (для двустороннего } \\
\text { пассажирского и грузового сообщения) }\end{array}$ & ДАПП Шара-Сур (РФ) - Тэс (Монголия) \\
\hline & $\begin{array}{l}\text { Автомобильный (для двустороннего } \\
\text { пассажирского и грузового сообщения) }\end{array}$ & $\begin{array}{l}\text { ДАПП Цаган-Толгой (РФ) - Арц-Сурь } \\
\text { (Монголия) }\end{array}$ \\
\hline & $\begin{array}{l}\text { Автомобильный (для двустороннего } \\
\text { пассажирского и грузового сообщения) }\end{array}$ & ДАПП Хандагайты (РФ) - Боршо (Монголия) \\
\hline \multirow[t]{3}{*}{ Республика Бурятия } & $\begin{array}{l}\text { Автомобильный (для двустороннего } \\
\text { пассажирского и грузового сообщения) }\end{array}$ & ДАПП Монды (РФ) - Ханх (Монголия) \\
\hline & $\begin{array}{l}\text { Автомобильный (для международного } \\
\text { пассажирского и грузового сообщения) }\end{array}$ & МАПП Кяхта (РФ) - Алтан-Булак (Монголия) \\
\hline & $\begin{array}{l}\text { Железнодорожный (для международного } \\
\text { пассажирского и грузового сообщения) }\end{array}$ & ЖДПП Наушки (РФ) - Сухе-Батор (Монголия) \\
\hline \multirow[t]{3}{*}{ Забайкальский край } & $\begin{array}{l}\text { Автомобильный (для двустороннего } \\
\text { пассажирского и грузового сообщения) }\end{array}$ & $\begin{array}{l}\text { ДАПП Верхний Ульхун (РФ) - Ульхун } \\
\text { (Монголия) }\end{array}$ \\
\hline & $\begin{array}{l}\text { Автомобильный (для международного } \\
\text { пассажирского и грузового сообщения) }\end{array}$ & $\begin{array}{l}\text { МАПП Соловьевск (РФ) - Эренцав } \\
\text { (Монголия) }\end{array}$ \\
\hline & $\begin{array}{l}\text { Железнодорожный (для двустороннего } \\
\text { пассажирского и грузового сообщения) }\end{array}$ & $\begin{array}{l}\text { МАПП Соловьевск (РФ) - Эренцав } \\
\text { (Монголия) }\end{array}$ \\
\hline
\end{tabular}

Источник: Федеральное агентство по обустройству государственной границы Российской Федерации (Росграница). URL: http://rosgranitsa.ru/ru/node/3165

Source: Federal Agency for the Development of the State Border Facilities of the Russian Federation. Available at: http://rosgranitsa.ru/ru/node/3165

\section{Список литературы}

1. Кылгыдай А.К.Ч., Осодоев П.В. Российско-монгольское приграничное сотрудничество на современном этапе. В кн.: Природоохранное сотрудничество в трансграничных экологических регионах: Россия - Китай - Монголия. Вып. 3. Ч. 2. Чита: Поиск, 2012. С. 18-21.

2. Приграничные и трансграничные территории Азиатской России и сопредельных стран (проблемы и предпосылки устойчивого развития): сб. статей / под ред. П.Я. Бакланова, А.К. Тулохонова. Новосибирск: Изд-во СО РАН, 2010. С. 5-7. 
3. Спирин П.П. Состояние интеграционных связей и проблемы приграничного сотрудничества западносибирских регионов. В кн.: Приграничные и трансграничные территории Азиатской России и сопредельных стран (проблемы и предпосылки устойчивого развития) / под ред. П.Я. Бакланова, А.К. Тулохонова. Новосибирск: Изд-во СО РАН, 2010. С. 385.

4. Осодоев П.В., Дамба Д. Экономическое сотрудничество Республики Бурятия и Монголии. В кн.: Приграничные и трансграничные территории Азиатской России и сопредельных стран (проблемы и предпосылки устойчивого развития) / под ред. П.Я. Бакланова, А.К. Тулохонова. Новосибирск: Изд-во СО РАН, 2010. С. 404.

5. Мешанинов B.M. Россия - Монголия: Приграничное и региональное сотрудничество и интеграционные процессы в Северо-Восточной Азии // Азия и Африка сегодня. 2005. № 11. C. $28-31$.

6. Приграничное сотрудничество: Россия, Монголия, Китай: материалы международной конференции. Чита: Экспресс-издательство, 2008. 208 с.

7. Шаралдаева И.А., Ващенко Е.В. Перспективы торгово-экономического сотрудничества с Монголией в Концепции развития приграничных территорий РФ // ФЭС: Финансы. Экономика. Стратегия. 2015. № 3. C. 12-15.

8. Гранберг А.Г. Стратегия территориального социально-экономического развития России: от идеи к реализации // Вопросы экономики. 2001. № 9. С. 15-27.

9. Безруков Л.А. Транспортно-экономические барьеры в развитии Сибири // ЭКО. 2012. № 7. С. 56-73.

10. Атанов Н.И., Мункодугарова А.Б. Экономическая динамика Забайкальской России и Монголии: приграничные сравнения трансформационного периода // ЭКО. 2014. № 12. С. 86-98.

11. Галкин Д.Г. Перспективы приграничного сотрудничества России и Монголии на макрои мезоуровне: материалы научной конференции «Ломоносовские чтения на Алтае: фундаментальные проблемы науки и образования». Барнаул: Изд-во Алтайского гос. ун-та, 2014. С. 2705-2709.

12. Ададимова Л.Ю. Оценка трансграничных факторов и приграничное сотрудничество на участке государственной границы Республики Тыва - Монголии: материалы XIV международной научной конференции «Россия: тенденции и перспективы развития». М.: Изд-во ИНИОН РАН, 2014. C. 209-303.

13. Ададимова Л.Ю. Трансграничные факторы и приграничное сотрудничество Республики Тыва и Монголии: материалы международной научно-практической конференции «Трансформация экономических отношений и парадигма развития аграрного сектора национальных экономик в условиях глобальных вызовов». Ростов-н/Д: АзовПечать, 2014. С. 248-252.

14. Ойдуn Т.М., Кылгылай А.К.Ч., Полулях Ю.Г. $и$ др. Оценка трансграничных факторов территориальной организации хозяйства в приграничных районах Республики Тыва // Политематический сетевой электронный научный журнал Кубанского государственного аграрного университета. 2011. № 74. C. 409-424. URL: http://ej.kubagro.ru/2011/10/pdf/41.pdf.

\section{Информация о конфликте интересов}

Мы, авторы данной статьи, со всей ответственностью заявляем о частичном и полном отсутствии фактического или потенциального конфликта интересов с какой бы то ни было третьей стороной, который может возникнуть вследствие публикации данной статьи. Настоящее заявление относится к проведению научной работы, сбору и обработке данных, написанию и подготовке статьи, принятию решения о публикации рукописи. 
ISSN 2311-875X (Online)

National Interests

ISSN 2073-2872 (Print)

\title{
CROSS-BORDER COOPERATION OF THE REGIONS OF SIBERIA AND MONGOLIA
}

\section{Ai-kys Ch. KYLGYDAI ${ }^{\mathrm{a}, \bullet}$, Tana M. OIDUP ${ }^{\mathrm{b}}$}

\author{
a Tuvinian Institute for Exploration of Natural Resources, Siberian Branch of Russian Academy of Sciences, \\ Kyzyl, Republic of Tyva, Russian Federation \\ aikys_k@mail.ru \\ b Tuvinian Institute for Exploration of Natural Resources, Siberian Branch of Russian Academy of Sciences, \\ Kyzyl, Republic of Tyva, Russian Federation \\ tana_o@mail.ru \\ - Corresponding author
}

\section{Article history:}

Received 9 September 2016

Received in revised form

2 October 2016

Accepted 26 October 2016

Available online

27 February 2017

JEL classification: F02, F53, O53, O57, Z18

Keywords: border regions, cooperation, border crossing point the expansion and deepening of cross-border cooperation.

\begin{abstract}
Importance The article overviews the cross-border cooperation of the regions of Siberia and Mongolia, and the regions situated on the Russian-Mongolian border in particular.

Objectives The research analyzes the location of each border region in particular, determines the level of cooperation between two parties. We also evaluate how actively local authorities use resource associated with border location, and what are real reasons that border activities are so weak. Methods The research represents a comparative analysis of cooperation between the regions of Siberia and Mongolia.

Results We identified which border regions were mostly involved into cross-border cooperation, and what role the quantity of border crossing points played, especially their status. To expand crossborder cooperation, it is necessary to increase a network of border crossing points, make them internationally significant, rather than bilateral, and modernize the border infrastructure.

Conclusions and Relevance The economic effect of cross-border cooperation implies the expansion of the distribution market for one part, and availability of cheaper goods and services for the other. It is worth mentioning that any positive administrative efforts may stall and have zero effect if there is no good border infrastructure. The findings will be helpful for all parties who are involved in
\end{abstract} (C) Publishing house FINANCE and CREDIT, 2016

\section{References}

1. Kylgydai A.K.Ch., Osodoev P.V. Rossiisko-mongol'skoe prigranichnoe sotrudnichestvo na sovremennom etape. V kn.: Prirodookhrannoe sotrudnichestvo v transgranichnykh ekologicheskikh regionakh: RossiyaKitai-Mongoliya. Vyp. 3. Ch. 2 [The Russian-Mongolian cross-border cooperation at the current stage. In: Cooperation for environmental protection in transborder environmental regions: Russia - China Mongolia. Issue 3. Part 2]. Chita, Poisk Publ., 2012, pp. 18-21.

2. Prigranichnye i transgranichnye territorii Aziatskoi Rossii i sopredel'nykh stran: problemy i predposylki ustoichivogo razvitiya [Border and trans-border territories of the Asian part of Russia and neighboring countries: issues and background of sustainable development]. Novosibirsk, Siberian Branch of RAS Publ., 2010, pp. 5-7.

3. Spirin P.P. Sostoyanie integratsionnykh svyazei i problemy prigranichnogo sotrudnichestva zapadnosibirskikh regionov. V kn.: Prigranichnye i transgranichnye territorii Aziatskoi Rossii i sopredel'nykh stran: problemy i predposylki ustoichivogo razvitiya [The state of integration ties and issues of trans-border cooperation of the West Siberian regions. In: Border and trans-border territories of the Asian part of Russia and neighboring countries: issues and background of sustainable development]. Novosibirsk, Siberian Branch of RAS Publ., 2010, p. 385.

4. Osodoev P.V., Damba D. Ekonomicheskoe sotrudnichestvo Respubliki Buryatiya $i$ Mongolii. $V$ kn.: Prigranichnye i transgranichnye territorii Aziatskoi Rossii i sopredel'nykh stran: problemy $i$ predposylki ustoichivogo razvitiya [Economic cooperation of the Republic of Buryatia and Mongolia. In: Border and trans-border territories of the Asian part of Russia and neighboring countries: issues and background of sustainable development]. Novosibirsk, Siberian Branch of RAS Publ., 2010, p. 404.

5. Meshchaninov V.M. [Russia-Mongolia: Border and regional cooperation and integration processes in Northeast Asia]. Aziya i Afrika segodnya = Asia and Africa Today, 2005, no. 11, pp. 28-31. (In Russ.) 
6. Prigranichnoe sotrudnichestvo: Rossiya, Mongoliya, Kitai: materialy mezhdunarodnoi konferentsii [Proc. Int. Sci. Conf. Border Cooperation: Russia, Mongolia, China]. Chita, Ekspress-izdatel'stvo Publ., 2008, $208 \mathrm{p}$.

7. Sharaldaeva I.A., Vashchenko E.V. [Prospects for economic and trade cooperation with Mongolia as part of the concept for developing border areas of the Russian Federation]. FES: Finansy. Ekonomika. Strategiya $=$ FES: Finance. Economy. Strategy, 2015, no. 3, pp. 12-15. (In Russ.)

8. Granberg A.G. [The strategy of territorial socio-economic development of Russia: from idea to implementation]. Voprosy Ekonomiki, 2001, no. 9, pp. 15-27. (In Russ.)

9. Bezrukov L.A. [Transport and economic barriers to Siberia's development]. EKO $=E C O, 2012$, no. 7, pp. 56-73. (In Russ.)

10. Atanov N.I., Munkodugarova A.B. [Economic trends of the Transbaikal areas of Russia and Mongolia: a comparison of border regions in the transformation period]. $E K O=E C O, 2014$, no. 12, pp. 86-98. (In Russ.)

11. Galkin D.G. [Prospects of border cooperation between Russia and Mogolia at the macro- and microlevel]. Lomonosovskie chteniya na Altae: fundamental'nye problemy nauki i obrazovaniya: materialy nauchnoi konferentsii [Proc. Sci. Conf. Lomonosov Readings in the Altai region: Fundamental Issues of Science and Education]. Barnaul, Altai State University Publ., 2014, pp. 2705-2709.

12. Adadimova L.Yu. [Evaluating transborder factors and border cooperation on the State borders of the Tuva Republic and Mongolia]. Rossiya: tendentsii i perspektivy razvitiya: materialy XIV mezhdunarodnoi nauchnoi konferentsii [Proc. $14^{\text {th }}$ Int. Sci. Conf. Russia: Development Trends and Prospects]. Moscow, INION RAS Publ., 2014, pp. 209-303.

13. Adadimova L.Yu. [Trans-border factors and cross-border cooperation of the Tuva Republic and Mongolia]. Transformatsiya ekonomicheskikh otnoshenii i paradigma razvitiya agrarnogo sektora natsional'nykh ekonomik $v$ usloviyakh global'nykh vyzovov: materialy mezhdunarodnoi nauchno-prakticheskoi konferentsii [Proc. Sci. Conf. Transformation of Economic Relationships and Development Paradigm of Agricultural Sectors of National Economies Through the Lens of Global Challenges]. Rostov-on-Don, AzovPechat' Publ., 2014, pp. 248-252.

14. Oidup T.M., Kylgydai A.K.Ch., Polulyakh Yu.G. et al. [Evaluating trans-border factors of geographical organization of economy in border districts of the Tuva Republic]. Politematicheskii setevoi elektronnyi nauchnyi zhurnal Kubanskogo gosudarstvennogo agrarnogo universiteta, 2011, no. 74, pp. 409-424. (In Russ.) Available at: http://ej.kubagro.ru/2011/10/pdf/41.pdf.

\section{Conflict-of-interest notification}

We, the authors of this article, bindingly and explicitly declare of the partial and total lack of actual or potential conflict of interest with any other third party whatsoever, which may arise as a result of the publication of this article. This statement relates to the study, data collection and interpretation, writing and preparation of the article, and the decision to submit the manuscript for publication. 